DOI: $10.30519 /$ ahtr.917210

Advances in Hospitality and Tourism Research (AHTR)

\title{
INFLUENCE OF INTERNET ON TOURISM CONSUMER BEHAVIOUR: A SYSTEMATIC REVIEW
}

\author{
Ernesto BATISTA SÁNCHEZ ${ }^{1}$ \\ M.A. International Tourism, Kemmy Business School, University of Limerick, Ireland \\ ORCID: 0000-0003-1271-4249
}

\section{Jim DEEGAN}

National Centre for Tourism Policies, Kemmy Business School, University of Limerick, Ireland ORCID: 0000-0003-1333-2795

\author{
Elizabeth del Carmen PÉREZ RICARDO \\ Department of Tourism, Business School, University of Holguin, Cuba \\ ORCID: 0000-0002-6649-2488
}

\begin{abstract}
This paper aims at identifying the state of academic research on the influence of Internet on tourism consumer behaviour. The Preferred Reporting Items for Systematic Reviews and MetaAnalyses (PRISMA) Methodology was used to select the data and the analysis was complemented with bibliometric indicators. This research identified 83 relevant articles related to the influence of Internet on tourism consumer behaviour. The systematic review of the academic literature demonstrated that the Internet influences tourism consumer behaviour during the entire travel cycle stages. During the pre-consumption stage, motivations and decisionmaking process are highly influenced by several online sources. However, in the case of expectations, limited research was found on this area. Value co-creation behaviour is influenced by Internet during the final two stages of the travel cycle stages. Finally, evidence suggests that loyalty is influenced during the consumption and post-consumption stages. These results provide a categorized analysis of the influence of Internet on the behavioural variables during each of the travel cycle stages for academicians and practitioners. The analysis was conducted on two major academic databases: Web of Science Core Collection and Scopus. The inclusion of other data sources and other types of secondary data could complement these results.
\end{abstract}

\section{Article History}

Received 16 April 2021

Revised 24 September 2021

Accepted 25 September 2021

Published online 11 Oct. 2021

\section{Keywords}

tourism consumer behaviour Internet

travel stage cycle

\footnotetext{
${ }^{1}$ Address correspondence to Ernesto Batista Sánchez, M.A. International Tourism, Kemmy Business School, University of Limerick, Ireland. E-mail: ebatistas@yahoo.com
} 


\section{INTRODUCTION}

Tourism consumer behaviour (TCB) comprehends the group of activities, experiences, decisions involved in the obtaining and consumption of a tourism product or service (Cohen, et al., 2014). Several research works in the marketing field have been carried out to understand the drivers related to this construct and its relationships with other concepts of tourism, becoming one of the most popular research topics in tourism (Bigné et al., 2009; Cohen et al., 2014; Gössling et al., 2012; Moutinho, 1987; Strandberg et al., 2018; Swarbrooke \& Horner, 2006; Tsang \& Hsu, 2011).

According to Cohen et al. (2014), during the first decade of the new millennium, scholars focused on determining how consumers behave during the decision-making process, which the motivations that influence their decisions are, and the influence that expectations and perceptions have on satisfaction and further loyalty to the product or tourism destination. However, the Internet also allowed tourists to become value co-creators of the tourist experience, changing their behaviour under the servicedominant logic theory (Buhalis \& Sinarta, 2019; Marine-Roig \& Clavé, 2016; Yi \& Gong, 2013). Tourists interact with online content during all different stages of the travel cycle: pre-consumption, consumption and postconsumption. Therefore, the development of methods to understand and predict those behaviours plays a key role in the future performance of tourism companies and destinations (Couture et al., 2015; Sotiriadis \& van Zyl, 2013; Tsang \& Hsu, 2011).

Cohen et al. (2014) conducted a review using a narrative approach of the articles in three major tourism academic journals between 2000 and 2012. Their results identified the main variables of TCB and its external influences. Serra Cantallops and Salvi (2014) used six major journals to analyse the influence of electronic word-of-mouth (eWOM) in the hotel industry between 2009-2014. Their study concluded that research was developed under two main lines: the review-generating factors and the impact of eWOM. Ulker-Demirel and Ciftci (2020) analysed the implementation of the Theory of Planned Behaviour in tourism, leisure and hospitality management. The authors concluded that in terms of managerial issues, there is still a lack of academic research in this area.

Based on the previous studies, it can be concluded that while there is abundant literature on this topic, it is scattered because the approaches that have been adopted analysed the travel cycle stages separately. Although several literature reviews and bibliometric analyses have been conducted in 
the past on this topic, to the best knowledge of the author, none of them has attempted to systematize the influence of the internet on TCB.

Therefore, this paper will focus on the variables of tourism consumer behaviour, i.e. motivations, expectations, decision-making, value cocreation, loyalty, and how they are influenced by the Internet. In this regard, this paper addresses and explores the following research questions:

- How has research related to the Internet and tourism consumer behaviour evolved over time?

- Which authors and journals are the most influential?

- Which publications are the theoretical basis for the studies on this field?

- How does Internet influence tourism consumer behaviour during the travel stage cycle?

To answer the research questions, a literature review was conducted based on a large body of academic articles. The conceptual analysis evidence that TCB is expressed by a tourist through five behavioural variables: motivation, expectation, decision-making, value co-creation, and loyalty. From the travel cycle stages perspective, these behavioural variables are present in the entire process and are influenced by the different sources of information.

This study analyses the influence of the Internet on tourism consumer behaviour using bibliometric techniques and content analysis. First, using bibliometric indicators, the study presents a list of the most influential journals, authors and the geographical distribution of the main research institutions. Secondly, the co-citation analysis provides some insights of the main theoretical clusters that support this research field. Finally, through content analysis, a categorization of the variables of tourism consumer behaviour is carried out during all the travel stage cycle, contributing to the existing academic body.

\section{LITERATURE REVIEW}

\section{Consumer Behaviour}

Consumer behaviour is considered to be the process that involves specific decisions, ideas, experiences or activities that satisfy a consumer wants or needs (Cohen et al., 2014). It refers to the process where consumer acquires and organizes information that leads to a purchase decision, its consumption and further evaluation (Moutinho, 1987). Among the 
marketing studies, consumer behaviour is one of the most researched topics by scholars. However, due to its complexity as a construct, consumer behaviour studies on tourism have focused on key conceptual variables that explain the behaviour of tourists during the travel cycle stages. Consumer behaviour theory in tourism has several unique characteristics that are different from other sectors. Tourism consumption is based on an investment with no tangible return which means that tourists will not expect any material return from their investment on holidays (Buhalis \& Sinarta, 2019; Moutinho, 1987).

Several authors have agreed that consumer behaviour needs to be studied through the analysis of psychological variables (Cohen et al., 2014; Ma et al., 2016). TCB is a complex construct, that is formed during the interaction of other constructs studied in tourism (Cohen et al., 2014). To the extent of this study, a group of five variables will be considered in the analysis of the process of tourism consumer behaviour, that is present during the entire travel cycle. During the pre-consumption stage, scholars agree that TCB is influenced by motivations, expectations and the decisionmaking process (Afonso et al., 2018; Li \& Cai, 2012; Qu, 2018; Rong et al., 2012).

Despite several years of study, researchers found difficult to evaluate $\mathrm{TCB}$, the Internet and social media apps, significantly improved the evaluation tools and provided tourists and marketers new forms of interaction. Therefore, the value co-creation behaviour emerged in TCB theory as a new form of behaviours (Buhalis, 2019; Lončarić et al., 2019; Pera, 2017). After the consumption stage, a fundamental concept of tourism behaviour is loyalty, specially under the scope of behavioural loyalty, in the process when tourists decide to recommend or re-produce the consumption experience (Bigné et al., 2001; Cohen et al., 2014; Lanfranchi et al., 2015).

\section{Role of The Internet and New Information Sources On Tourism Consumer Behaviour}

Several marketing studies have been focused on identifying the role of information sources on TCB. Information sources are considered as a potential influence during the pre-consumption stage when the information is consulted and used by tourists (Frías et al., 2008). Moreover, information can be considered as the most important factor in influencing TCB (Murphy et al., 2007). Tourists require several types of information during all the consumption stage (Vogt \& Stewart, 1998). 
However, technological changes impacted the entire process of tourism consumption. The evolution of the Internet had several implications in the tourism industry and the ways companies launch their products and services online. Technology helps potential tourists to make better travel decisions and reduces their fear and risks perception (Buhalis \& Sinarta, 2019). Therefore, the Internet changed the understanding of TCB and the role of sources of information, changing the ways in which customers plan, buy and consume tourism products (Del Chiappa et al., 2016).

Travellers share their stories in social media and forum sites and employ different un-structures big data sources like photos, videos, online comments, among others. Hence, traditional word-of-mouth communications dramatically changed with the Internet. Electronic worthof-mouth (eWOM) became more relevant with the development of new online tools. This study utilizes the concept of Litvin et al. (2008, p. 461) considering eWOM as "all informal communications directed at consumers through Internet-based technology related to the usage or characteristics of particular goods and services, or their sellers".

According to scholars, the importance and fundamental difference between eWOM and WOM relies on the number of people who can be reached using the Internet. eWOM influence more tourists because of its speed and convenience, as well as the absence of face-to-face human pressure (Serra Cantallops \& Salvi, 2014; Sun et al., 2006). From a consumer perspective, eWOM represents an opportunity to disseminate their feelings regarding a product or service and influence another consumers behaviour (Chen et al., 2015).

\section{METHODOLOGY}

Following the approach suggested by Reyes-Menendez et al. (2019), the Preferred Reporting Items for Systematic Reviews and Meta-Analyses (PRISMA) methodology was employed, as presented in figure 1. The raw data used in this study was collected from the Web of Science Core Collection and Scopus, two of the most relevant academic databases recognized by scholars (Benckendorff \& Zehrer, 2013; Saha et al., 2020). Similar to previous studies, the analysis only included articles written in English (Morosan \& Bowen, 2018). Keywords were selected from terms commonly employed in the literature of this construct and were combined using the database operators to guarantee several output results. The inclusion criteria considered the presence of these keywords in the "Title, 
abstract or keywords" section (Table 1). Data was collected in January of 2021 and the total number of articles retrieved from this initial screening was 225.

Table 1. Research criteria

\begin{tabular}{|c|c|c|}
\hline Databases & \multirow{2}{*}{\multicolumn{2}{|c|}{$\begin{array}{l}\text { Web of Science Core Collection and Scopus } \\
\text { Consumer behaviour, tourist behaviour, tourism, online, eWOM, online } \\
\text { reviews, UGC, C2C, B2C }\end{array}$}} \\
\hline Keywords & & \\
\hline Search within & \multicolumn{2}{|l|}{ Topic (Title, Abstract and Keywords) } \\
\hline $\begin{array}{l}\text { Document } \\
\text { Type }\end{array}$ & \multicolumn{2}{|l|}{ Article } \\
\hline Language & \multicolumn{2}{|l|}{ English } \\
\hline Research Area & \multicolumn{2}{|l|}{ All } \\
\hline Identification & $\begin{array}{c}\text { \# of records identified through database } \\
\text { searching: } \mathbf{2 2 5}\end{array}$ & \\
\hline \multirow[t]{2}{*}{ Screening } & $\begin{array}{c}\text { \# of records after duplicates removed: } \\
187\end{array}$ & \\
\hline & & $\begin{array}{c}\text { Excluded after the analysis of Title } \\
\text { and Abstract: } \mathbf{7 4}\end{array}$ \\
\hline \multirow[t]{2}{*}{ Eligibility } & $\begin{array}{l}\text { \# of full-text articles assessed for eligibility: } \\
\qquad 113\end{array}$ & \\
\hline & & $\begin{array}{l}\text { Excluded after full-read analysis: } \\
\mathbf{3 0}\end{array}$ \\
\hline Included & $\begin{array}{l}\text { \# of full text included for the analysis: } \\
\qquad \mathbf{8 3}\end{array}$ & \\
\hline
\end{tabular}

Figure 1. PRISMA 2009 Flow Diagram

The second step of the PRISMA methodology is to remove duplicate articles retrieved from the search. Using EndNote Reference Manager, a search for duplicate files was conducted to exclude them from the dataset, obtaining an output of 187 articles. Thirdly, while the selection process considered the presence of the keywords in the mentioned sections, through the full reading of titles and abstracts, articles not related to the industry or to the purpose of this study were found, even when they included some of the selected keywords. A total of 74 articles were excluded from the research, obtaining a list of 113 articles. The last step included a full-text analysis of the article to select the final sample to include in the systematic review. When reading the articles in-depth, 30 papers did not match with the inclusion criteria for the research or were inadequate for it, because led to inconclusive results or they were not in the scope of this investigation. Hence, a final list of 83 articles was selected for the analysis. 
The bibliometric analysis developed employed two main techniques, evaluative methods and relational methods. The evaluative methods included productivity and impact metrics. Productivity metrics analyses the evolution of the research topic in the field and identifies the most influential journals and authors. The geographical distribution of research institutions analysis was performed using Microsoft Excel and VosViewer (Koseoglu et al., 2016; Qian et al., 2018, 2019). Impact metrics considered citation analysis, specifically h-index indicator. Relational methods were used while conducting the co-citation analysis of the references. Co-citation is considered as the most common bibliometric indicator employed to present the clusters of co-citation pairs (Leung et al., 2017). Finally, this paper employs a qualitative approach to analyse and categorize the variables of tourism consumer behaviour during the travel cycle stages.

\section{RESULTS}

The analysis of the 83 articles evidences an increasing interest by the academic community on this topic. Since 1998 when Bonn et al. (1998) published their article in the Journal of Hospitality and Tourism Research, scholars have developed substantial research, as presented in Figure 2.

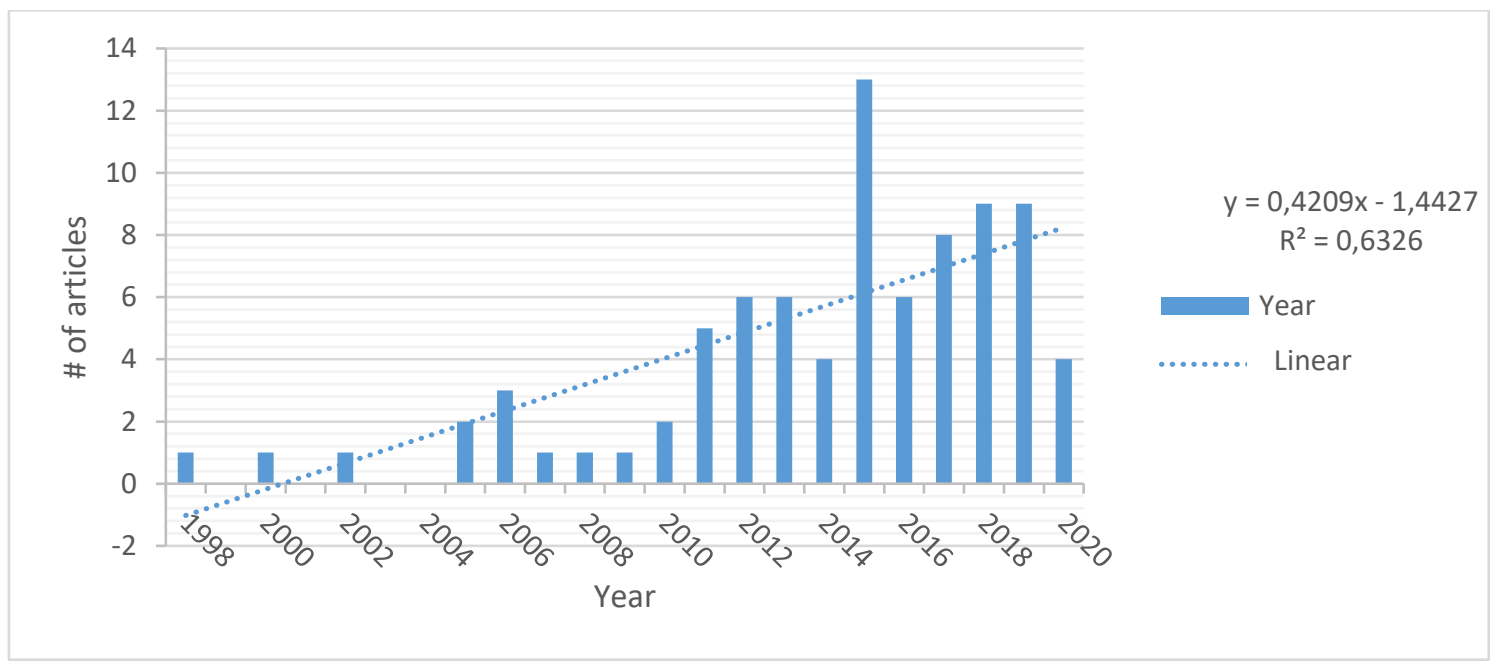

Figure 2. Articles per year in the area of study

\section{Productivity per journals}

The articles have been published in 47 journals, being Tourism Management, Journal of Travel and Tourism Marketing and Journal of Travel Research the most employed by authors to share their findings. Five journals gather $36 \%$ of the total research in this field, as presented in Table 2. 
Table 2. Productivity of the main journals

\begin{tabular}{|c|c|c|c|c|}
\hline Source & Documents & Citations & $\begin{array}{c}\% \text { of total } \\
\text { documents }\end{array}$ & $\begin{array}{c}\text { Cumulative } \\
\text { percentage }\end{array}$ \\
\hline Tourism management & 9 & 784 & 10.84 & 10.84 \\
\hline Journal of travel and tourism marketing & 7 & 320 & 8.43 & 19.27 \\
\hline Journal of travel research & 6 & 239 & 7.23 & 26.50 \\
\hline Annals of tourism research & 4 & 473 & 4.82 & 31.32 \\
\hline $\begin{array}{l}\text { International journal of contemporary } \\
\text { hospitality management }\end{array}$ & 4 & 112 & 4.82 & 36.14 \\
\hline $\begin{array}{l}\text { Journal of hospitality and tourism } \\
\text { technology }\end{array}$ & 4 & 117 & 4.82 & 40.96 \\
\hline $\begin{array}{l}\text { International journal of culture, tourism, } \\
\text { and hospitality research }\end{array}$ & 3 & 8 & 3.61 & 44.57 \\
\hline Asia pacific journal of tourism research & 2 & 24 & 2.41 & 46.98 \\
\hline Information technology and tourism & 2 & 5 & 2.41 & 49.39 \\
\hline $\begin{array}{l}\text { International journal of hospitality } \\
\text { management }\end{array}$ & 2 & 324 & 2.41 & 51.80 \\
\hline Internet research & 2 & 193 & 2.41 & 54.21 \\
\hline $\begin{array}{l}\text { Journal of retailing and consumer } \\
\text { services }\end{array}$ & 2 & 260 & 2.41 & 56.62 \\
\hline Online information review & 2 & 86 & 2.41 & 59.03 \\
\hline
\end{tabular}

Furthermore, the up-to-dateness of the published articles was analysed to describe the publication pattern in the last five years. From the total amount of articles, 49 were published in the last five-year period, for a Price's Index of 0.5936. Furthermore, data showed that five journals have published two articles each on this topic, while 34 journals have published at least one article on this topic since 2015, as presented in Table 3.

Table 3. Main journals with published articles in the area of study since 2015

\begin{tabular}{lcc}
\hline Journal Title & $\mathbf{2 0 1 5 - 2 0 2 0}$ & \% of total \\
\hline Tourism Management & 5 & 10.20 \\
International Journal of Contemporary Hospitality Management & 3 & 6.12 \\
International Journal of Culture, Tourism, and Hospitality Research & 3 & 6.12 \\
Journal of Travel and Tourism Marketing & 3 & 6.12 \\
Journal of Travel Research & 3 & 6.12 \\
\hline
\end{tabular}

\section{Co-citation of references}

The co-citation analysis was performed on the most cited references found in the analysed articles. A total of 5062 bibliographic references were found in the 83 articles, selecting for the cluster analysis papers with a minimum of four citations. Hence, the co-citation analysis was conducted on 27 articles. The cluster analysis was developed using the association strength method with VOSviewer software, obtaining three main academic clusters. 
The first cluster, presented in green colour, includes eight articles $(29.62 \%)$. Among them, there is a pioneering paper on the Technology Acceptance Model (Davis, 1989) that is the theoretical basis of several further articles. The second relevant article of this cluster is the Model of Information Systems Success (DeLone \& McLean, 2003), which supports several research works on e-commerce and online tourism behaviour. The second cluster (red colour) comprises ten articles (37.03\%) that are the pioneers in the analysis of the influence of eWOM and user-generated content on tourism. One of the relevant articles in this cluster is a conceptual model of the role of eWOM in hospitality and tourism management (Litvin et al., 2008). The final cluster (blue colour) includes nine articles (33.33\%) and comprises some of the pioneer papers that analysed the impact of online content in tourism consumer behaviour, especially the influence on the decision-making process.

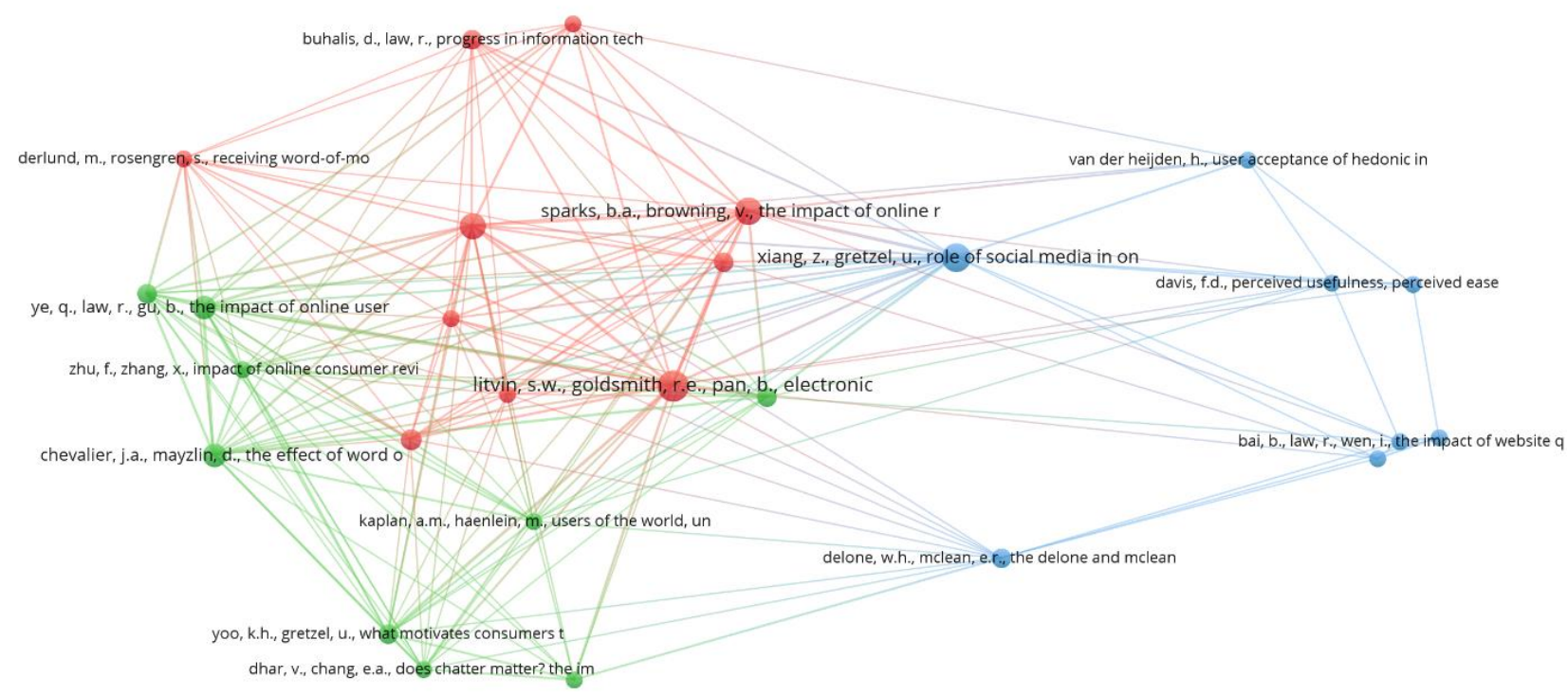

B vosviewer

Figure 3. Co-Citation network and Clusters

\section{Authors' productivity}

Citation analysis evidence that Rob Law and Eleonora Pantano are the most productive authors and present on the same time the higher h-Index. The description of the breakdown of the main authors per article is presented in Table 4. 
Table 4. h-Index of the most relevant authors

\begin{tabular}{lccc}
\hline Author & Documents & Citation Sum Within H-Core & H-Index \\
\hline Law R. & 5 & 822 & 5 \\
Pantano E. & 3 & 117 & 3 \\
Fesenmaier D.R. & 2 & 436 & 2 \\
Park S. & 2 & 180 & 2 \\
Backman S.J. & 2 & 168 & 2 \\
Vu H.Q. & 2 & 137 & 2 \\
Bai B. & 2 & 119 & 2 \\
Li G. & 2 & 98 & 2 \\
Di Pietro L. & 2 & 87 & 2 \\
Hernández-Méndez J. & 2 & 67 & 2 \\
\hline
\end{tabular}

\section{Geographical distribution of the research institutions}

The geographical distribution of the authors' institutions evidence that $17.95 \%$ are researchers located in the United States, followed by $11.97 \%$ in Spain and $6.48 \%$ in Australia (Table 5). However, the topic has gained interest in Malaysia, China, and South Korea since 2015.

Table 5. Geographical distribution of the research institutions

\begin{tabular}{lcc}
\hline Country & Documents & \% of total \\
\hline United States & 21 & 17.95 \\
Spain & 14 & 11.97 \\
Australia & 8 & 6.84 \\
China & 8 & 6.84 \\
Italy & 8 & 6.84 \\
United Kingdom & 8 & 6.84 \\
Hong Kong & 6 & 5.13 \\
South Korea & 4 & 3.42 \\
Taiwan & 4 & 3.42 \\
Canada & 3 & 2.56 \\
Portugal & 3 & 2.56 \\
Austria & 2 & 1.71 \\
Czech Republic & 2 & 1.71 \\
Greece & 2 & 1.71 \\
Malaysia & 2 & 1.71 \\
Turkey & 2 & 1.71 \\
\hline
\end{tabular}

Influence of the internet on tourism consumer behaviour during the travel cycle stage

Several scholars have considered the analysis of the variables of tourism consumer behaviour (TCB) under the framework of the travel cycle stage. During the pre-consumption stage of the travel cycle, where tourists engage in the decision-making process, scholars conclude that motivations and expectations are formed. Once the decision is made and the tourism product 
or service is consumed, tourists engage in value co-creation behaviours. Finally, in the post-consumption stage, consumers' loyalty is expressed by the recommendation or re-purchase intention behaviour.

Traditionally, these sets of relationships have been considered linear. The influence was dominated by tourism providers advertising, and other sources like word-of -mouth was limited because of their reach levels. However, the Internet has a dual role in the influence of TCB. On one hand, the Internet is a facilitator of certain types of behaviours since consumers can develop the entire decision-making process on their own on the Internet. On the other hand, the Internet influences certain TCB. The infrastructure development on the tourism providers' facilities guaranteeing access to the Internet has allowed tourists to engage in realtime co-creation behaviours, especially on social media. Hence, this study explores the existing relationships to verify the hypotheses that the Internet influences tourism consumer behaviour during all travel cycle stages. The description of the results is presented using the travel stage process as a framework for the TCB, as presented in figure 4.

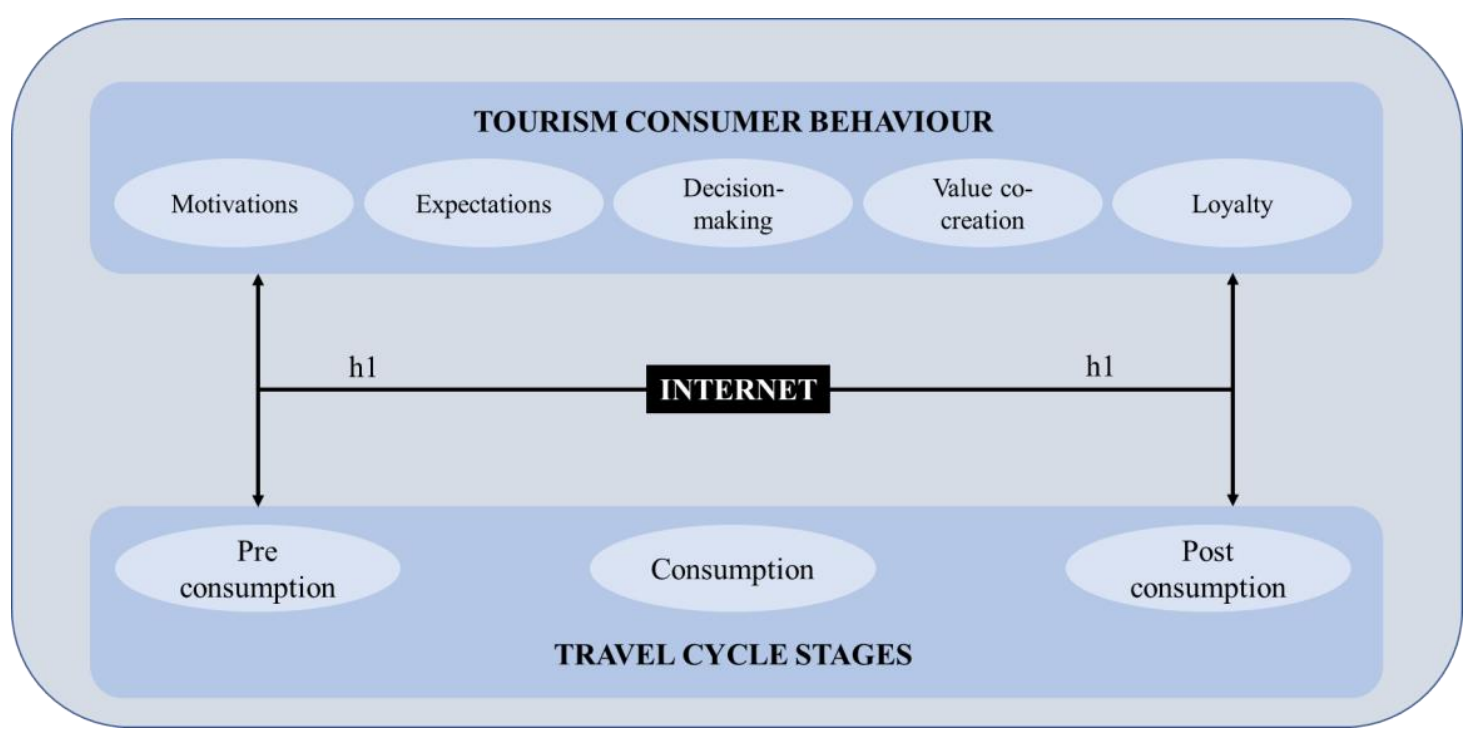

Figure 4. Influence of the Internet on TCB during the travel cycle stages

\section{Pre-consumption stage}

Several studies have been conducted to analyse the impact of the internet on tourism consumer behaviour during the travel cycle. The pioneer studies explored how pleasure travellers would engage with the Internet in the decision-making process (Bonn et al., 1998; Legoh É Rel \& Guéguen, 2000). These earlier results showed that over $70 \%$ of customers were willing to use the Internet for travel-related seeking information process. Similarly, 
demographic analysis evidence that young people browse information for their trips online (Rong et al., 2012). Poria and Taylor (2002) found that the Internet influences the decision-making process for specific demographic market segments such as gays and lesbians since they could remain anonymous during the purchasing process. Furthermore, hotels that provide information using descriptive terminology familiar to them such as "gay-friendly" have a greater positive influence on their decision.

A study in Spain identified that women are more influenced to buy travel-related products online, as well as people between 35 and 44 years old (Garín-Muñoz \& Pérez-Amaral, 2011). However, a study conducted in the European Union found gender differences being men more frequent online buyers than women and that the frequency of online travel-related buying depends on the nationality of the consumers (Szopiński \& Staniewski, 2016) and the level of Internet penetration in the society (GarínMuñoz \& Pérez-Amaral, 2011). These results are similar to the findings of Martins et al. (2015) who expressed that males are more prone to purchase online. Complementary analysis of the types of devices used by Czech tourists during the online search of information evidence that they prefer desk computer or laptop because it is perceived as more comfortable. However, once in the destination, tourists use mobile or smartphones, especially male tourists (Vaško \& Abrhám, 2015).

Law and Bai (2008) identified differences in tourist behaviour using the Internet, classifying tourists between buyers and browsers. Furthermore, they concluded that the purchase behaviour on websites increases with age, education level, and income. Western tourists are more incline to buy than Asians, who tend to browse. Tourists with buying behaviour rate more important products or services information, its quality, and purchase information. Other important elements that influence their purchase behaviour is website interface and navigation easiness. It was determined that travel website quality influences purchase behaviour.

Couture et al. (2015) affirmed that tourists with innovative behaviour are more willing to engage in the information search process online and that tourism innovativeness influences the online tourism consumer behaviour on the pre-consumption stage. They use proactive communication with tourism companies to look for information and help during the decisionmaking process, especially using chat applications. Email, on the other hand, is employed for complaints when tourists are not satisfied with the product or service consumed. Wozniak et al. (2018) analysed the use of smartphones during the travel cycle journey and found that self-efficacy, 
mobile-specific innovativeness, and personal attachment influence behaviour. Moreover, data suggest that the most innovative is the target group, the more willing is to book using the mobile, share an experience or write a review. Similarly, Bajpai and Lee (2015) found that in Taiwan the information search on the internet is one of the major determinants of online consumer behaviour during the decision-making process.

Pan and Fesenmaier (2006) proposed a conceptual model based on vacation destination planning through the Internet. According to their findings, decision-making online is composed of a set of hierarchical structures and that tourists have a different set of semantic mental models than the ones used by providers online. Travel planning is a complex process that faces several issues to be solved during the stages of the process. Besides, results suggest that each tourist has a different semantic model regarding a destination; therefore, they navigate through information using unique paths. Common online tourism behaviour showed that accommodation choices are made first, which indicates the importance of accommodation for the tourist.

A deeper analysis conducted in a study of 380 tourists in Portugal by Martins et al. (2015) evidence that five factors influence the online decisionmaking process. The first factor is convenience and satisfaction since the internet allows customers to purchase their tourist experience without travelling, waiting or dealing with unpleasant sellers (Martins et al., 2015). Couture et al. (2015) further concluded that immediate response has a greater influence on the pre-consumption stage since tourists are expecting a quick answer. The second factor is availability, recognized by tourists as the fact that the Internet is always available and that it influences their decisions. The third factor identified is information and planning, based on the amount of information that a tourist has on the Internet and the increasing exposure to travel-related information flow. Fourth, the Internet facilitates the evaluation of alternatives that allow tourists to fulfil easily their wants and needs related to the specific destinations. Finally, the last factor denominated bad experience relates to the availability of all types of information related to the product the tourist desires and the perception that buying online avoids intermediaries that increase the final price of the product. Furthermore, the authors found empirical evidence that the Internet influences two stages of the purchasing decision of the tourists: the evaluation of the alternatives and the purchase (Martins et al., 2015).

According to Öz (2015), social media is used by $56 \%$ of tourists on the pre-consumption stage of the travel cycle and it has a significant 
influence on the decision-making process. Tourists employ social media sites to get information related to the destination, hotel, attractions, transportation, prices, and travel budget, besides food and beverage information. Additionally, Kim et al. (2017) developed an analysis on the use of mobile social media networks (MSMN) by Korean senior tourists showing that $46.4 \%$ employed these sites between 10 and 29 minutes per day. Of all respondents, $91.6 \%$ used a smartphone to connect to MSMN and $80.4 \%$ used social media for posting or searching information, especially while being at home (64\%). In addition, $48.8 \%$ used social media to purchase tourism products, being Facebook the most frequently search engine employed (17\%). Similarly, the study conducted by Shen et al. (2020) on smart tourists found evidence that social network sites influence tourists during the three phases of consumption. However, the study unveiled a more influential relationship during the two first phases of consumption. Smart technologies influence sustainable behaviour in the pre-consumption stage of the tourist journey. These types of technologies are also more employed in the two first phases of the consumption process.

The study of Xiang et al. (2015) found evidence of the adoption of the Internet in the travel planning process. The study of American tourists showed that the influence of the Internet in the pre-consumption process is across all generations although generation $Y$ is perceived as more engaged in the travel planning process online. Even more, they found that social media significantly influences travel planning, especially those sites where tourists can share pictures and videos. The adoption of Smartphones technologies has reduced the use of printed maps and increased the engagement with GPS and geo collaborative tools while tourists are at the tourism destination. Moreover, several significant decisions such as restaurants or sites to visit are made in the site because of the role of technology as a facilitator of information. These results support the analysis of Chung et al. (2011) who studied the influence of online content such as interactive maps in tourism consumer behaviour. Network analysis demonstrated that interactive maps increase the perceptions of engagement and trip planning in heritage activities more than traditional list displays. Furthermore, the study evidence that online interactivity influences attitudes and perceptions through a tourist product, service or destination.

Huang et al. (2016) analysed from the Technology Acceptance Model how ease of use of a virtual reality tool influences potential tourism experience and their behavioural intentions of visiting the destination. The results evidence that easiness to use a virtual tool enhances the experience and even more, websites using virtual reality influence the behavioural 
intention of tourists, especially because of the utilization of multimedia content. The perception of autonomy during the use of virtual reality tools is positively correlated to behavioural intentions to take a trip. Hwang et al. (2018) found evidence that extrinsic and intrinsic motivation on social media influences booking intentions. Elements such as relevance, flexibility, completeness, timeliness, and trustworthiness of the information received through social media positively influence travel behaviour and their satisfaction with online reviews and to purchase online.

One of the elements that influence the adoption of the internet in the decision-making process is perceived risk and trust (Hua et al., 2017). Izquierdo-Yusta and Martínez-Ruiz (2011) identified that the lack of trust in the Internet as a distribution channel negatively influences purchase decision. On the other hand, the analysis of the influence of Smart Booking Mobile Application in the airline industry demonstrated that smart pricing and security influences trust (Pradhan, 2019). Similarly, Bonsón Ponte et al. (2015) expressed that the influence of the Internet in purchasing behaviour is related to the perceived trusts and security of the online provider. Evidence suggests that Internet privacy concerns, the provider's reputation, and website investment are the main factors that influence online purchase.

Arsal et al. (2010) concluded that residents and experienced travellers' opinions in travel websites influence traveller's decision. A deeper analysis showed that experienced travellers' opinions are influential regarding travel-related issues such as transportation, accommodation, and monetary issues. On the other hand, residents influence travel decisions related to food and beverage, travel itineraries within the destination, as well as safety. These results supported the study of Beldona et al. (2005) who concluded that online shopping motivations of travel products in low and high complexity web environments are different and depend on user's skills related to online purchasing. Low complexity purchases, such as car rental are driven by transactional motivations while high complex purchases such as tours are influenced by informational parameters. High skilled users are influenced by the information parameters on their purchase behaviour. However, low skilled ones are influenced by availability parameters, especially related to accommodation services.

The study (Sabiote-Ortiz et al., 2016) on British and Spanish tourists showed that the Internet influences purchase decision due to the level of responsiveness, especially for Spanish tourists who avoid high uncertainty levels. On the other hand, British tourists, and those from similar cultures with a high level of uncertainty avoidance, are influenced when privacy and 
efficacy are perceived (Sabiote-Ortiz et al., 2016). A study of Turkish tourists (Alvarez \& Asugman, 2006) evidenced the presence of two main categories, the online explorers and the risk-averse planners. The first group are less influenced by the content to complete the purchase online. Evidence of Turkish tourists showed that this group is fundamentally composed of males, who have negative attitudes toward various sources of information. On the other hand, the group of risk-averse planners are more influenced by the Internet and spend more time exploring travel-related content. This type of tourists are particularly female (Alvarez \& Asugman, 2006).

\section{Consumption stage}

During the consumption stage of the travel cycle, tourists engage in value co-creation. According to Shen et al. (2020), social media significantly influence tourists in the consumption stage. Co-creation behaviour occurs in online reviews, where customers engage during the consumption of the experience. Storytelling in online reviews is an influential co-creation behaviour form. Storytelling reflects the whole consumption experience and influences other tourists decisions (Pera, 2017). Di Pietro et al. (2012) found that the use of Facebook by tourists expressing their judgment through a destination influences the tourism destination image. Öz (2015) concluded that social media influence tourist behaviour during the consumption stage because they use it to get information about travel. Besides, co-creation behaviour occurs in the consumption stage when having a mobile Internet connection during the consumption. It was found that value co-creation occurs when they share videos and pictures related to their experience during the consumption. Lee and Hyun (2015) studied the psychological factors that influence consumer behaviour and concluded that the socialization process among peers in online virtual communities influence behavioural intentions, especially related to follow travel advice from peers.

Similarly, Ben-Shaul and Reichel (2018) found evidence that the strongest consumer motives influence the degree of participation in virtual communities. The evidence showed that there is a positive and strong correlation between these two variables on Facebook. Pantano and Pietro's (2013) findings showed that Facebook is used limitedly for informative purposes on the decision-making process but highly used for complaining regarding the experience in the destination. The use of Facebook as an interactive platform for consumers to share their experiences in a userfriendly free platform and the opportunity to interact with tourism providers made the platform more effective. 
In addition, there is a socio-psychological factor in value co-creation using Virtual Travel Communities (VTC) that relates to social interaction, information from previous tourists that support the decision and the interaction with people with similar interests. The study of Baglieri and Consoli (2009) found evidence that VTC boosts tourism innovation influencing customer relationships. These types of communities act as a form of value co-creation behaviour that benefits tourists and providers. This factor is perceived as a way to help tourism companies to be successful.

Co-creation on Facebook fans page is a hedonist motive for tourists that perceive it as a fun and entertained activity, as well as amusement from other customers (Ben-Shaul \& Reichel, 2018). The frequency of co-creation patterns such as frequency of entrance and duration of the social media activities are influenced by sociopsychological, hedonist, and functional motives. It has been demonstrated that there is a social need that correlated with the motivation of being a "knowledge producer", which explains the value co-creation behaviour of tourists online, even more in communities such as Facebook. Additionally, findings suggest that functional and hedonist motives are associated with the frequency and duration of the interaction on social media, while sociological motives influence the degree of contribution (Ben-Shaul \& Reichel, 2018).

\section{Post-consumption stage}

During the post-consumption stage, it was found that tourists only share videos and travel pictures. A $67 \%$ of the tourists engage in social media to share their experiences, if they are extremely satisfied with the experience, and $52 \%$ engage if they are dissatisfied. Even more, extreme sentiments regarding the experience influence the engagement with social media sharing (Öz, 2015). The study on Serbian tourists found evidence that the main motivation to post a review is to help other vacationers, a prosocial behaviour that is altruist and intends to help another person. Contradictory to literature, evidence was not found to affirm that there are significant differences in the motive to prosocial online behaviour regarding age groups. However, the study showed differences regarding gender and online sharing, being females the ones with a higher propensity to engage in online sharing (Mladenovic et al., 2019).

According to Ben-Shaul and Reichel (2018), the degree of participation in value co-creation influences customer loyalty. The level of recognition of the tourist as an active participant on a tourism Facebook brand page is a predictor of customer loyalty, in its level of revisiting or 
recommending to other tourists. Moreover, it was demonstrated that there is a relationship between the level of frequency and duration of the visit to the page with revisit intentions. Additionally, a study (Rong et al., 2012) in Hong Kong evidences that young people are more willing to share their experiences online than the elder ones. Educated people also engage in online sharing experiences more often than other demographic segments. Furthermore, past experiences influence sharing and browsing behaviour. People who travel long distances on their last trip, especially overseas, are more prone to look for online travel information, read online comments, and share their experiences online (Rong et al., 2012).

Ring et al. (2016) categorized tourists by the type of content used when recommending or sharing a tourist experience. The first group is called the online visualists and are characterized by the use of visual information. Evidence suggests that senior tourists are more likely to be visualists when sharing their experiences. Online verbalists segments, on the other hand, refer to those tourists who share their experiences using written language instead of sharing pictures and is mainly characteristic of female tourists.

\section{DISCUSSION}

During the pre-consumption stage, three main behavioural variables are influenced by the Internet: motivations, expectations, and decision-making. Motivations and expectations are formed by an accumulative process of reception of information through different sources. Therefore, the complexity of identifying the influence of the Internet on these variables is significant. However, the analysis of moderator variables has been used to explain this phenomenon. Elements such as flexibility, the relevance of the information, and convenience are relevant to influence tourism motivation on the Internet (Hwang et al., 2018; Martins et al., 2015). In fact, motivations are different in relation to the complexity level of the purchase travel product and tourists' skills. In the case of the formation of expectations through the Internet, surprisingly little research was found (Park \& Nicolau, 2015).

Decision-making on the internet, on the other hand, has been well documented by academic research and several factors arose from them. First, early studies anticipated that tourists would engage with the Internet, especially due to the opportunity that it presented for access to information (Bonn et al., 1998; Legoh É Rel \& Guéguen, 2000). Furthermore, the impact has been widely accepted on three stages of the decision-making process: 
information search, the alternative of evaluation, and purchase decision (Bajpai \& Lee, 2015; Pan \& Fesenmaier, 2006). Using a gender approach, studies have concluded that the influence of the Internet on information search is higher in females than males (Garín-Muñoz \& Pérez-Amaral, 2011). Females are influenced by online visual content, especially multimedia and storytelling content (Alvarez \& Asugman, 2006; Ring et al., 2016). Males, on the other hand, are influenced by content related to functional benefit and are prone to complete the purchase decision more frequent than females (Alvarez \& Asugman, 2006). Lastly, the influence of the Internet in the decision-making process is limited by the Internet penetration in the society (Garín-Muñoz \& Pérez-Amaral, 2011), cultural characteristics (Hagag et al., 2015) and nationality (Sabiote-Ortiz et al., 2012; Szopiński \& Staniewski, 2016).

During the consumption stage of the travel cycle, scholars have found that tourists engage in value co-creation behaviour. Three factors facilitate this type of behaviour: the access to new types of communication devices, the infrastructure conditions of the tourism destinations, and social media sites. During the consumption, stage tourists engage to share their experiences only if they have access to Internet connection (Öz, 2015) and using mobile phones (Vaško \& Abrhám, 2015). Furthermore, co-creation behaviour during the consumption stage is related to picture and video sharing, and micro-blogging. Social media sites such as Facebook provide an interactive user-friendly platform (Pantano \& Pietro, 2013) where tourists engage in a perceived fun and entertained activity (Ben-Shaul \& Reichel, 2018).

During the post-consumption stage, the Internet also influences cocreation behaviour and loyalty. Co-creation behaviour in the postconsumption stage is related to prosocial behaviour that motivates tourists to write a post on their trip experience (Mladenovic et al., 2019), especially in the case of long haul trips (Rong et al., 2012). Evidence regarding a consumer participation behaviour type of value co-creation was not found in the analysed literature.

In the case of loyalty, traditional theories consider that it is expressed by the intention to recommend and revisit a destination. However, the results of this study showed that in the case of online environments, loyalty does not necessarily follow this longitudinal process approach. Tourists interact online with the providers and other tourists sharing reviews or posts, recommending the experience during and after the consumption which can be measured as a loyalty indicator. Ben-Shaul and Reichel (2018) 
concluded that the level of recognition of a tourist on a Facebook fan page of a tourism provider or destination is a predictor of their loyalty. Besides, demographic characteristics and the level of satisfaction with the experience determine the level of recommendation on the Internet. In the postconsumption stage, tourists engage in social media share more positive than negative experiences, especially in sharing economies platforms such Airbnb (Öz, 2015; Pera et al., 2019).

\section{CONCLUSIONS}

This paper offers an overview of the "state of issue" related to the existing literature on the influence of the Internet on tourism consumer behaviour. Scholars have studied TCB over the last six decades, providing several contributions. Moreover, TCB construct has been systematized by previous academicians who concluded that its main variables are motivations, expectations, decision-making, value co-creation, and loyalty (Cohen et al., 2014; Moutinho, 1987). However, the consensus has not been achieved yet on this topic, since it is a multidimensional and complex construct.

The adoption of the Internet drastically changed the role of the distribution channels of the tourism industry and the accessibility to information from the consumer perspective. Tourists are not only influenced by messages induced by tourism providers on traditional sources of information, but also by other tourists who expressed their opinions and experiences on the Internet (Xiang et al., 2015). Although several literature reviews have been conducted in the past on TCB (Cohen et al., 2014; Serra Cantallops \& Salvi, 2014; Ulker-Demirel \& Ciftci, 2020), to the author's knowledge, no systematic review has been conducted on the influence of the Internet on TCB. Thus, this research contributes to filling this academic gap, providing a deep analysis of how these behavioural variables are influenced during the different stages of travel cycle. From a methodological perspective, the PRISMA Methodology was selected to conduct the systematic reviews due to its applicability and re-applicability characteristic, under a rigorous scientific method (Moher et al., 2009; ReyesMenendez et al., 2019).

Therefore, this paper contributes to the understanding of how the Internet influences tourism consumer behaviour. While Cohen et al. (2014) analysed the main concepts of tourism consumer behaviour and how are they influenced by elements such as technology, demographic characteristics, and the context, our paper focused on the influence of the Internet. Similarly, Vanhala et al. (2020) studied the usage of large datasets 
in online consumer behaviour, however, their study is not specific to the tourism industry context, and it focused only on papers published since 2000 .

Using the previous conceptualization of the TCB construct as a starting point, this research attempts to find evidence on the academic literature of the impact of the internet during all travel cycle stages. During the pre-consumption stage, motivations and decision-making processes are highly influenced by several online sources. However, in the case of expectations, limited research on this area was found. One of the elements to understand this phenomenon could be related to traditional approaches of the SERVQUAL model (Parasuraman et al., 1985) where expectations are typically analysed in relation to tourists' satisfaction.

Furthermore, evidence was found to conclude that value co-creation behaviour is influenced by the Internet during the final two stages of the travel cycle stages. Types of solicited behaviour in value co-creation online are still incipient according to academic literature, representing a further research area for academicians and practitioners. In the case of loyalty, evidence suggests that it is influenced by the Internet during the consumption and post-consumption stages.

The bibliometric analysis conducted identified the main journals and tendencies on the development of research in this field. Tourism management is the most influential journal while Eleonora Pantano and Robert Law are the most prolific authors in this field. Second, the co-citation analysis conducted on the references allowed to identify the theoretical foundations of the papers analysed in this review. Research conducted to identify the influence of the Internet on behavioural variables rely on the foundations of the Technology Acceptance Model. Third, the detailed review conducted allowed the categorization of the results according to the main behavioural variables during each of the travel cycle stages. The systematic review of the literature provides scholars and practitioners with a summarized "state of issue" of TCB during the entire travel cycle stages.

Some suggestion and managerial implications can be summarized from this research. As the study found, tourism consumer behaviour is influenced in a higher state during the first two stages of the travel cycle. Therefore, online content generated by tourism providers should aim to position messages that enhance tourists' motivations and expectations toward the destination. Advertising strategies and marketing campaign should consider decision-making process from an experiential perspective instead of the rational approach. Furthermore, the creation of content 
should be conducted under co-creation strategies, where consumers interact in the value creation process. In the specific case of social media, big data technologies provide an opportunity for practitioners to customize and re-design their message in real-time. The implementation of eyetracking technologies or sentiment analysis on social media platforms can provide managers with information to personalize messages and content.

The main limitations of this paper are that data was collected only from the Scopus and Web of Science databases. Other academic databases should be included for a deeper analysis and comparisons. Despite the growing number of studies, several research gaps remain to be filled on further research. The adoption of unstructured methods of analysis provided by artificial intelligence tools might facilitate sentiment analysis on eWOM. Although some studies have attempted to analyse real-time value co-creation (Buhalis \& Sinarta, 2019) on the Internet or used geotagged photos (Vu et al., 2015) to evaluate TCB, the amount of research conducted is significantly short. Further research should be conducted in this area, especially to conceptually delimitate the influence of value cocreation behaviour on the Internet on loyalty.

\section{REFERENCES}

Afonso, C., Silva, G. M., Gonçalves, H. M., \& Duarte, M. (2018). The role of motivations and involvement in wine tourists' intention to return: SEM and fsQCA findings. Journal of Business Research, 89, 313-321. doi: 10.1016/j.jbusres.2017.11.042

Alvarez, M., \& Asugman, G. (2006). Explorers versus planners: A study of Turkish tourists. Annals of Tourism Research, 33(2), 319-338. doi: 10.1016/j.annals.2005.12.001

Arsal, I., Woosnam, K. M., Baldwin, E. D., \& Backman, S. J. (2010). Residents as Travel Destination Information Providers: An Online Community Perspective. Journal of Travel Research, 49(4), 400-413. doi: 10.1177/0047287509346856

Baglieri, D., \& Consoli, R. (2009). Collaborative innovation in tourism: Managing virtual communities. TQM Journal, 21(4), 353-364. doi: 10.1108/17542730910965065

Bajpai, A., \& Lee, C.-W. (2015). Consumer behavior in e-tourism services: A case of Taiwan. Tourism and Hospitality Management, 21(1), 1-17.

Beldona, S., Morrison, A. M., \& O'Leary, J. (2005). Online shopping motivations and pleasure travel products: A correspondence analysis. Tourism Management, 26(4), 561-570. doi: 10.1016/j.tourman.2004.03.008

Benckendorff, P., \& Zehrer, A. (2013). A Network Analysis of Tourism Research. Annals of Tourism Research, 43, 121-149. doi: 10.1016/J.ANNALS.2013.04.005

Ben-Shaul, M., \& Reichel, A. (2018). Motives, Modes of Participation, and Loyalty Intentions of Facebook Tourism Brand Page Consumers. Journal of Travel Research, 57(4), 453-471. doi: 10.1177/0047287517704087

Bigné, J. E., Sánchez, M. I., \& Sánchez, J. (2001). Tourism image, evaluation variables and after purhase behaviour: Inter-relationship. Tourism Management, 22(6), 607-616. doi: 10.1016/S0261-5177(01)00035-8 
Bonn, M. A., Furr, H. L., \& Susskind, A. M. (1998). Using the Internet as a Pleasure Travel Planning Tool: An Examination of the Sociodemographic and Behavioral Characteristics Among Internet Users and Nonusers. Journal of Hospitality $\mathcal{E}$ Tourism Research, 22(3), 303-317. doi: 10.1177/109634809802200307

Bonsón Ponte, E., Carvajal-Trujillo, E., \& Escobar-Rodríguez, T. (2015). Influence of trust and perceived value on the intention to purchase travel online: Integrating the effects of assurance on trust antecedents. Tourism Management, 47, 286-302. doi: 10.1016/j.tourman.2014.10.009

Buhalis, D. (2019). Technology in tourism-from information communication technologies to eTourism and smart tourism towards ambient intelligence tourism: A perspective article. Tourism Review, 75(1), 267-272. doi: 10.1108/TR-06-2019-0258

Buhalis, D., \& Sinarta, Y. (2019). Real-time co-creation and nowness service: Lessons from tourism and hospitality. Journal of Travel and Tourism Marketing, 36(5), 563-582. doi: 10.1080/10548408.2019.1592059

Chen, C.-H., Nguyen, B., Klaus, P. “Phil," \& Wu, M.-S. (2015). Exploring Electronic Wordof-Mouth (eWOM) in The Consumer Purchase Decision-Making Process: The Case of Online Holidays - Evidence from United Kingdom (UK) Consumers. Journal of Travel \& Tourism Marketing, 32(8), 953-970. doi: 10.1080/10548408.2014.956165

Chung, J. Y., Anuar, F. I., Go, H., \& Gretzel, U. (2011). Influence of interactive thematic maps on tourist perceptions: A network analysis. Journal of Hospitality and Tourism Technology, 2(3), 216-234. doi: 10.1108/17579881111173767

Cohen, S. A., Prayag, G., \& Moital, M. (2014). Consumer behaviour in tourism: Concepts, influences and opportunities. Current Issues in Tourism, 17(10), 872-909. doi: 10.1080/13683500.2013.850064

Couture, A., Arcand, M., Sénécal, S., \& Ouellet, J.-F. (2015). The Influence of Tourism Innovativeness on Online Consumer Behavior. Journal of Travel Research, 54(1), 6679. doi: $10.1177 / 0047287513513159$

Davis, F. D. (1989). Perceived usefulness, perceived ease of use, and user acceptance of information technology. MIS Quarterly: Management Information Systems, 13(3), 319-339. doi: 10.2307/249008

Del Chiappa, G., Alarcón-Del-Amo, M. D. C., \& Lorenzo-Romero, C. (2016). Internet and User-Generated Content Versus High Street Travel Agencies: A Latent Gold Segmentation in the Context of Italy. Journal of Hospitality Marketing and Management, 25(2), 197-217. doi: 10.1080/19368623.2014.1001933

DeLone, W. H., \& McLean, E. R. (2003). The DeLone and McLean model of information systems success: A ten-year update. Journal of Management Information Systems, 19(4), 9-30. M.E. Sharpe Inc. doi: 10.1080/07421222.2003.11045748

Di Pietro, L., Di Virgilio, F., \& Pantano, E. (2012). Social network for the choice of tourist destination: Attitude and behavioural intention. Journal of Hospitality and Tourism Technology, 3(1), 60-76. doi: 10.1108/17579881211206543

Frías, D. M., Rodríguez, M. A., \& Castañeda, J. A. (2008). Internet vs. Travel agencies on pre-visit destination image formation: An information processing view. Tourism Management, 29(1), 163-179. doi: 10.1016/j.tourman.2007.02.020

Garín-Muñoz, T., \& Pérez-Amaral, T. (2011). Internet usage for travel and tourism: The case of Spain. Tourism Economics, 17(5), 1071-1085. doi: 10.5367/te.2011.0080

Hagag, W., Clark, L., \& Wheeler, C. (2015). A framework for understanding the website preferences of Egyptian online travel consumers. International Journal of Culture, Tourism, and Hospitality Research, 9(1), 68-82. doi: 10.1108/IJCTHR-03-2013-0008 
Hua, L. Y., Ramayah, T., Ping, T. A., \& (Jacky), C. J. H. (2017). Social Media as a Tool to Help Select Tourism Destinations: The Case of Malaysia. Information Systems Management, 34(3), 265-279. doi: 10.1080/10580530.2017.1330004

Huang, Y. C., Backman, K. F., Backman, S. J., \& Chang, L. L. (2016). Exploring the Implications of Virtual Reality Technology in Tourism Marketing: An Integrated Research Framework. International Journal of Tourism Research, 18(2), 116-128. doi: 10.1002/jtr.2038

Hwang, J., Park, S., \& Woo, M. (2018). Understanding user experiences of online travel review websites for hotel booking behaviours: An investigation of a dual motivation theory. Asia Pacific Journal of Tourism Research, 23(4), 359-372. doi: 10.1080/10941665.2018.1444648

Izquierdo-Yusta, A., \& Martínez-Ruiz, M. P. (2011). Assessing the consumer's choice of purchase channel in the tourism sector: Evidence from Spain. EuroMed Journal of Business, 6(1), 77-99. doi: 10.1108/14502191111130325

Kim, M. J., Lee, C. K., \& Bonn, M. (2017). Obtaining a better understanding about travelrelated purchase intentions among senior users of mobile social network sites. International Journal of Information Management, 37(5), 484-496. doi: 10.1016/j.ijinfomgt.2017.04.006

Koseoglu, M. A., Rahimi, R., Okumus, F., \& Liu, J. (2016). Bibliometric studies in tourism. Annals of Tourism Research, 61, 180-198. doi: 10.1016/J.ANNALS.2016.10.006

Lanfranchi, M., Giannetto, C., \& De Pascale, A. (2015). A General model for analyzing the factors that influence tourists' destination loyalty in rural areas. Quality - Access to Success, 16(148), 68-74.

Law, R., \& Bai, B. (2008). How do the preferences of online buyers and browsers differ on the design and content of travel websites? International Journal of Contemporary Hospitality Management, 20(4), 388-400. doi: 10.1108/09596110810873507

Lee, K. H., \& Hyun, S. S. (2015). A model of behavioral intentions to follow online travel advice based on social and emotional loneliness scales in the context of online travel communities: The moderating role of emotional expressivity. Tourism Management, 48, 426-438. doi: 10.1016/j.tourman.2014.12.012

Legoh É Rel, P., \& Guéguen, N. (2000). Selling tourism on the internet: Analysis of the balance of power between seller and consumer during information exchange and negotiation. Journal of Travel and Tourism Marketing, 9(3), 49-64. doi: 10.1300/J073v09n03_04

Leung, X. Y., Sun, J., \& Bai, B. (2017). Bibliometrics of social media research: A co-citation and co-word analysis. International Journal of Hospitality Management, 66, 35-45. doi: 10.1016/j.ijhm.2017.06.012

Li, M., \& Cai, L. A. (2012). The Effects of Personal Values on Travel Motivation and Behavioral Intention. Journal of Travel Research, 51(4), 473-487. doi: 10.1177/0047287511418366

Litvin, S. W., Goldsmith, R. E., \& Pan, B. (2008a). Electronic word-of-mouth in hospitality and tourism management. Tourism Management, 29(3), 458-468. doi: 10.1016/j.tourman.2007.05.011

Litvin, S. W., Goldsmith, R. E., \& Pan, B. (2008b). Electronic word-of-mouth in hospitality and tourism management. Tourism Management, 29(3), 458-468. doi: 10.1016/j.tourman.2007.05.011

Lončarić, D., Perišić Prodan, M., \& Dlačić, J. (2019). The role of market mavens in cocreating tourist experiences and increasing loyalty to service providers. Economic 
Research-Ekonomska Istrazivanja, 32(1), 2252-2268. doi: 10.1080/1331677X.2019.1645713

Ma, J., Campos, A. C., Li, S., Gardiner, S., \& Scott, N. (2016). Attention, emotion and hedonic service experiences: Managing and delivering services in the Asian Century. Worldwide Hospitality and Tourism Themes, 8(1), 53-60. doi: 10.1108/WHATT-10-2015-0033

Marine-Roig, E., \& Clavé, S. A. (2016). Destination Image Gaps Between Official Tourism Websites and User-Generated Content. In Information and Communication Technologies in Tourism 2016 (pp. 253-265). Springer International Publishing. doi: 10.1007/978-3-319-28231-2_19

Martins, C., Salazar, A., \& Inversini, A. (2015). The internet impact on travel purchases: Insights from Portugal. Tourism Analysis, 20(2), 251-258. doi: 10.3727/108354215X14265319207632

Mladenovic, D., Krajina, A., \& Milojevic, I. (2019). Motives for writing online reviews in post-vacation phase. International Journal of Culture, Tourism, and Hospitality Research, 13(2), 244-256. doi: 10.1108/IJCTHR-12-2018-0169

Moher, D., Liberati, A., Tetzlaff, J., \& Altman, D. G. (2009). Preferred Reporting Items for Systematic Reviews and Meta-Analyses: The PRISMA Statement. PLoS Medicine, 6(7), e1000097. doi: 10.1371/journal.pmed.1000097

Morosan, C., \& Bowen, J. T. (2018). Analytic perspectives on online purchasing in hotels: A review of literature and research directions. International Journal of Contemporary Hospitality Management, 30(1), 557-580. doi: 10.1108/IJCHM-10-2016-0566

Moutinho, L. (1987). Consumer Behaviour in Tourism. European Journal of Marketing, 21(10), 5-44. doi: 10.1108/EUM0000000004718

Murphy, L., Mascardo, G., \& Benckendorff, P. (2007). Exploring word-of-mouth influences on travel decisions: Friends and relatives vs. Other travellers. International Journal of Consumer Studies, 31(5), 517-527. doi: 10.1111/j.1470-6431.2007.00608.x

Öz, M. (2015). Social media utilization of tourists for travel-related purposes. International Journal of Contemporary Hospitality Management, 27(5), 1003-1023. doi: 10.1108/IJCHM-01-2014-0034

Pan, B., \& Fesenmaier, D. R. (2006). Online Information Search. Vacation Planning Process. Annals of Tourism Research, 33(3), 809-832. doi: 10.1016/j.annals.2006.03.006

Pantano, E., \& Pietro, L. Di. (2013). From e-tourism to f-tourism: Emerging issues from negative tourists' online reviews. Journal of Hospitality and Tourism Technology, 4(3), 211-227. doi: 10.1108/JHTT-02-2013-0005

Parasuraman, A., Zeithaml, V. A., \& Berry, L. L. (1985). A Conceptual Model of Service Quality and Its Implications for Future Research. Journal of Marketing, 49(4), 41. doi: $10.2307 / 1251430$

Park, S., \& Nicolau, J. L. (2015). Asymmetric effects of online consumer reviews. Annals of Tourism Research, 50, 67-83. doi: 10.1016/j.annals.2014.10.007

Pera, R. (2017). Empowering the new traveller: Storytelling as a co-creative behaviour in tourism. Current Issues in Tourism, 20(4), 331-338. doi: 10.1080/13683500.2014.982520

Pera, R., Viglia, G., Grazzini, L., \& Dalli, D. (2019). When empathy prevents negative reviewing behavior. Annals of Tourism Research, 75, 265-278. doi: 10.1016/j.annals.2019.01.005

Poria, Y., \& Taylor, A. (2002). I am not afraid to be gay when im on the net': Minimising social risk for lesbian and gay consumers when using the internet. Journal of Travel and Tourism Marketing, 11(2-3), 127-142. doi: 10.1300/J073v11n02_07 
Pradhan, B. B. (2019). A Study on the Impact of Self-efficacy and Smart Pricing in Customers' Acceptance of Airline B2C Smart Booking Mobile Application. Journal of Advanced Research in Dynamical and Control Systems, Volume 11(10-Special Issue), 429-433.

Qian, J, Wei, J., \& Law, R. (2018). Review of critical discourse analysis in tourism studies. International Journal of Tourism Research, 20(4), 526-537. doi: 10.1002/jtr.2202

Qian, Jianwei, Law, R., Wei, J., \& Wu, Y. (2019). Trends in Global Tourism Studies: A Content Analysis of the Publications in Tourism Management. Journal of Quality Assurance in Hospitality and Tourism, 20(6), 753-768. doi: 10.1080/1528008X.2019.1658149

$\mathrm{Qu}, \mathrm{J}$. (2018). A study on the development of Xitang's homestay tourism from the perspective of consumer purchase behaviour. Journal of Discrete Mathematical Sciences and Cryptography, 21(6), 1401-1406. doi: 10.1080/09720529.2018.1527485

Reyes-Menendez, A., Saura, J. R., \& Filipe, F. (2019). The importance of behavioral data to identify online fake reviews for tourism businesses: A systematic review. PeerJ Computer Science, 2019(9). doi: 10.7717/peerj-cs.219

Ring, A., Tkaczynski, A., \& Dolnicar, S. (2016). Word-of-Mouth Segments. Journal of Travel Research, 55(4), 481-492. doi: 10.1177/0047287514563165

Rong, J., Vu, H. Q., Law, R., \& Li, G. (2012). A behavioral analysis of web sharers and browsers in Hong Kong using targeted association rule mining. Tourism Management, 33(4), 731-740. doi: 10.1016/j.tourman.2011.08.006

Sabiote-Ortiz, C. M., Frías, D. M., \& Castañeda, J. A. (2012). E-service quality as antecedent to e-satisfaction: The moderating effect of culture. Online Information Review, 36(2), 157-174. doi: 10.1108/14684521211229011

Sabiote-Ortiz, C. M., Frías-Jamilena, D. M., \& Castañeda-García, J. A. (2016). Overall Perceived Value of a Tourism Service Delivered via Different Media. Journal of Travel Research, 55(1), 34-51. doi: 10.1177/0047287514535844

Saha, V., Mani, V., \& Goyal, P. (2020, April 1). Emerging trends in the literature of value co-creation: A bibliometric analysis. Benchmarking, Vol. 27, pp. 981-1002. Emerald Group Publishing Ltd. doi: 10.1108/BIJ-07-2019-0342

Serra Cantallops, A., \& Salvi, F. (2014). New consumer behavior: A review of research on eWOM and hotels. International Journal of Hospitality Management, 36, 41-51. doi: 10.1016/j.ijhm.2013.08.007

Shen, S., Sotiriadis, M., \& Zhou, Q. (2020). Could smart tourists be sustainable and responsible as well? The contribution of social networking sites to improving their sustainable and responsible behavior. Sustainability (Switzerland), 12(4), 1-21. doi: $10.3390 /$ su12041470

Sotiriadis, M. D., \& van Zyl, C. (2013). Electronic word-of-mouth and online reviews in tourism services: The use of twitter by tourists. Electronic Commerce Research, 13(1), 103-124. doi: 10.1007/s10660-013-9108-1

Sun, T., Youn, S., Wu, G., \& Kuntaraporn, M. (2006). Online Word-of-Mouth (or Mouse): An Exploration of Its Antecedents and Consequences. Journal of Computer-Mediated Communication, 11(4), 1104-1127. doi: 10.1111/j.1083-6101.2006.00310.x

Szopiński, T., \& Staniewski, M. W. (2016). Socio-economic factors determining the way etourism is used in European Union member states. Internet Research, 26(1), 2-21. doi: 10.1108/IntR-03-2014-0065

Tsang, N. K. F., \& Hsu, C. H. C. (2011). Thirty years of research on tourism and hospitality management in China: A review and analysis of journal publications. International Journal of Hospitality Management, 30(4), 886-896. doi: 10.1016/j.ijhm.2011.01.009 
Ulker-Demirel, E., \& Ciftci, G. (2020). A systematic literature review of the theory of planned behavior in tourism, leisure and hospitality management research. Journal of Hospitality and Tourism Management, 43, 209-219. doi: 10.1016/j.jhtm.2020.04.003

Vanhala, M., Lu, C., Peltonen, J., Sundqvist, S., \& Nummenmaa, J. (2020). The usage of large data sets in online consumer behaviour: A bibliometric and computational textmining - driven analysis of previous research. Journal of Business Research, 106(September 2019), 46-59. doi: 10.1016/j.jbusres.2019.09.009

Vaško, M., \& Abrhám, J. (2015). Issues of secure and sustainable e-tourism: Case of the czech republic. Journal of Security and Sustainability Issues, 5(2), 137-148. doi: 10.9770/jssi.2015.5.2(1)

Vogt, C. A., \& Stewart, S. I. (1998). Affective and cognitive effects of information use over the course of a vacation. Journal of Leisure Research, 30(4), 498-520. doi: 10.1080/00222216.1998.11949845

Vu, H. Q., Li, G., Law, R., \& Ye, B. H. (2015). Exploring the travel behaviors of inbound tourists to Hong Kong using geotagged photos. Tourism Management, 46, 222-232. doi: 10.1016/j.tourman.2014.07.003

Wozniak, T., Schaffner, D., Stanoevska-Slabeva, K., \& Lenz-Kesekamp, V. (2018). Psychological antecedents of mobile consumer behaviour and implications for customer journeys in tourism. Information Technology and Tourism, 18(1-4), 85-112. doi: 10.1007/s40558-017-0101-8

Xiang, Z., Magnini, V. P., \& Fesenmaier, D. R. (2015). Information technology and consumer behavior in travel and tourism: Insights from travel planning using the internet. Journal of Retailing and Consumer Services, 22, 244-249. doi: 10.1016/j.jretconser.2014.08.005

Yi, Y., \& Gong, T. (2013). Customer value co-creation behavior: Scale development and validation. Journal of Business Research, 66(9), 1279-1284. doi: 10.1016/j.jbusres.2012.02.026 